\title{
Article \\ Quantum-Mechanical Study of Nanocomposites with Low and Ultra-Low Interface Energies
}

\author{
Martin Friák ${ }^{1, *}$ (]) David Holec ${ }^{2}$ (i) and Mojmír Šob ${ }^{3,1,4}$ \\ 1 Institute of Physics of Materials, Academy of Sciences of the Czech Republic, Žižkova 22, \\ CZ-616 62 Brno, Czech Republic; mojmir@ipm.cz \\ 2 Department of Materials Science, Montanuniversität Leoben, Franz-Josef-Strasse 18, A-8700 Leoben, Austria; \\ david.holec@unileoben.ac.at \\ 3 Department of Chemistry, Faculty of Science, Masaryk University, Kotlářská 2, \\ CZ-611 37 Brno, Czech Republic \\ 4 Central European Institute of Technology, CEITEC MU, Masaryk University, Kamenice 5, \\ CZ-625 00 Brno, Czech Republic \\ * Correspondence: friak@ipm.cz; Tel.: +420-532-290-400
}

Received: 27 November 2018; Accepted: 12 December 2018; Published: 15 December 2018

\begin{abstract}
We applied first-principles electronic structure calculations to study structural, thermodynamic and elastic properties of nanocomposites exhibiting nearly perfect match of constituting phases. In particular, two combinations of transition-metal disilicides and one pair of magnetic phases containing the $\mathrm{Fe}$ and $\mathrm{Al}$ atoms with different atomic ordering were considered. Regarding the disilicides, nanocomposites $\mathrm{MoSi}_{2} / \mathrm{WSi}_{2}$ with constituents crystallizing in the tetragonal $\mathrm{C}_{1} 1_{b}$ structure and $\mathrm{TaSi}_{2} / \mathrm{NbSi}_{2}$ with individual phases crystallizing in the hexagonal C40 structure were simulated. Constituents within each pair of materials exhibit very similar structural and elastic properties and for their nanocomposites we obtained ultra-low (nearly zero) interface energy (within the error bar of our calculations, i.e., about $0.005 \mathrm{~J} / \mathrm{m}^{2}$ ). The interface energy was found to be nearly independent on the width of individual constituents within the nanocomposites and/or crystallographic orientation of the interfaces. As far as the nanocomposites containing $\mathrm{Fe}$ and $\mathrm{Al}$ were concerned, we simulated coherent superlattices formed by an ordered $\mathrm{Fe}_{3} \mathrm{Al}$ intermetallic compound and a disordered $\mathrm{Fe}-\mathrm{Al}$ phase with 18.75 at.\% $\mathrm{Al}$, the $\alpha$-phase. Both phases were structurally and elastically quite similar but the disordered $\alpha$-phase lacked a long-range periodicity. To determine the interface energy in these nanocomposites, we simulated seven different distributions of atoms in the $\alpha$-phase interfacing the $\mathrm{Fe}_{3} \mathrm{Al}$ intermetallic compound. The resulting interface energies ranged from ultra low to low values, i.e., from 0.005 to $0.139 \mathrm{~J} / \mathrm{m}^{2}$. The impact of atomic distribution on the elastic properties was found insignificant but local magnetic moments of the iron atoms depend sensitively on the type and distribution of surrounding atoms.
\end{abstract}

Keywords: $\mathrm{MoSi}_{2} ; \mathrm{WSi}_{2} ; \mathrm{TaSi}_{2} ; \mathrm{NbSi}_{2} ;$ elasticity; ab initio; interface energies; $\mathrm{Fe}_{3} \mathrm{Al}$; disorder

\section{Introduction}

Ever increasing demand for energy-conversion units exhibiting a higher efficiency leads to increasing operating temperatures in these systems and, therefore, new materials, which would sustain such conditions, are needed. Because the development of these materials is highly complex and multi-faceted, combinations of often mutually-conflicting properties are rarely found in a single-phase structures. Composites then represent a critically important class of materials. In particular, coherent nanocomposites require optimum matching of constituting phases for their stability and rather low interface energies. In our study, we addressed three nanocomposites combining materials intended for high or elevated temperature applications: two pairs of transition-metal disilicides that are predicted 
to possess ultra-low interface energies and then a pair of two different phases from the Fe-Al system, which are expected to have the interface energies ranging from ultra low to low values.

Regarding the transition-metal silicides, they are currently considered as very promising bases for future high-temperature structural materials (see, e.g., Refs. [1-4]), in particular for operational temperatures above those of Ni-based superalloys. At high temperatures, transition-metal silicides are known to combine the ductility and thermal conductivity of metals with high strength and corrosion resistance of ceramics. As far as composites combining them are concerned, $\mathrm{MoSi}_{2} / \mathrm{WSi}_{2}$ composite powders with different phase compositions are fabricated via a self-propagating high-temperature synthesis (SHS) method [5]. This approach is widely recognized as an effective manufacturing strategy for the fabrication of materials applied in high-temperature fields, in particular for refractories such as transition-metal carbides, nitrides, silicides, and borides [6]. Preparation of $\mathrm{MoSi}_{2} / \mathrm{WSi}_{2}$ composites using elemental powders of Mo, W and Si by the thermal explosion mode of SHS have been theoretically calculated and investigated by experiments in Ref. [7]. Phase composition and microchemical area analyses were conducted by XRD, SEM and EDAX methods. Pure $\mathrm{MoSi}_{2} / \mathrm{WSi}_{2}$ composites are fabricated by the thermal explosion mode of $\mathrm{SHS}$, and $\mathrm{MoSi}_{2} / \mathrm{WSi}_{2}$ exists as a solid solution of $\left(\mathrm{Mo}_{x}, \mathrm{~W}_{1-x}\right) \mathrm{Si}_{2}$ but the chemical elements inside of individual grains are not uniformly distributed. As an alternative processing route, five kinds of $\mathrm{WSi}_{2} / \mathrm{MoSi}_{2}$ composites are fabricated by mechanical alloying in [8]. WSi 2 -reinforced $\mathrm{MoSi}_{2}$ composites are successfully prepared also by mechanical activation followed by in situ reactive spark plasma sintering of $\mathrm{Mo}$, Si, and $\mathrm{W}$ elemental powders in [9]. The addition of $\mathrm{W}$ to the reactants leads to a finer microstructure than that obtained using pure $\mathrm{MoSi}_{2}$, resulting in a significant improvement of mechanical properties. The Vicker's hardness of $20 \mathrm{vol} \% \mathrm{WSi}_{2} / \mathrm{MoSi}_{2}$ is as high as $16.47 \mathrm{GPa}$. Nanocomposite of $(\mathrm{Mo}, \mathrm{W}) \mathrm{Si}_{2} / \mathrm{WSi}_{2}$ was synthesized via mechanical alloying (MA) and heat treatment in Ref. [10]. Increasing the milling time to $80 \mathrm{~h}$ followed by the post-annealing at $1000{ }^{\circ} \mathrm{C}$ caused the complete formation of $(\mathrm{Mo}, \mathrm{W}) \mathrm{Si}_{2} / \mathrm{WSi}_{2}$ nanocomposite. $\mathrm{MoSi}_{2} / \mathrm{WSi}_{2}$ composites were successfully prepared by pressureless sintering from mechanically-assisted combustion synthesized powders in [11].

Motivated by the above-mentioned studies of $\mathrm{MoSi}_{2} / \mathrm{WSi}_{2}$ (nano)composites containing structurally and elastically very similar pair of materials crystallizing in the $\mathrm{C} 11_{b}$ structure, we also assessed another pair of matching materials, $\mathrm{TaSi}_{2}$ and $\mathrm{NbSi}_{2}$, which are crystallizing in the C40 structure.

Finally, as a system with rather low interface energy, we studied nanocomposites formed by two phases from the Fe-Al binary system [12-15]. These materials are also considered as promising for elevated-temperature applications and as such they are intensively studied [16-40]. A sub-class of Fe-Al-based materials is represented by composites consisting of an ordered $\mathrm{Fe}_{3} \mathrm{Al}$ with the $\mathrm{DO}_{3}$ structure and a disordered Fe-Al solid solution with about 18-19 at.\% Al. The existence of these composites can be experimentally proved using, for example, Mössbauer spectroscopy [41] or transmission electron microscopy (TEM) techniques. The latter are sensitive to anti-phase boundaries (APBs), which have a different character in $\mathrm{Fe}_{3} \mathrm{Al}$ and the $\mathrm{Fe}-\mathrm{Al}$ phase [42-45].

\section{Methods}

Our quantum-mechanical calculations were performed within the framework of density functional theory [46,47] using the Vienna Ab initio Simulation Package (VASP) [48,49] and projector augmented wave (PAW) pseudopotentials [50,51]. When studying the transition-metal disilicides, the exchange and correlation energy was treated in the local density approximation (LDA) [52] but, in the case of phases containing the $\mathrm{Fe}$ and $\mathrm{Al}$ atoms, the generalized gradient approximation (GGA) parameterized by Perdew and Wang [53] (PW91) with the Vosko-Wilk-Nusair correction [54] was necessary to correctly reproduce the ground-state $\mathrm{DO}_{3}$ structure of $\mathrm{Fe}_{3} \mathrm{Al}$. Regarding the $\mathrm{MoSi}_{2}$ and $\mathrm{WSi}_{2}$, we used a plane-wave energy cut-off of $400 \mathrm{eV}$ and the k-point Monkhorst-Pack [55] meshes contained $20 \times 20 \times 2(10 \times 10 \times 8)$ k-points in the case of 24 -atom supercells modeling the superlattices with stacking along the [001] ([100] and [110]) directions. The calculations for $\mathrm{TaSi}_{2}$ and $\mathrm{NbSi}_{2}$ required the 
cut-off energy of $480 \mathrm{eV}$ and the $12 \times 12 \times 4$ k-point mesh in the case of 18-atom supercells. When computing Fe-Al-based nanocomposites, the cut-off energy was equal to $350 \mathrm{eV}$ and the sampling of the Brillouin zone was done using Monkhorst-Pack grids with $10 \times 10 \times 6$ k-points in the case of computational supercells containing 32 atoms. All calculations had an estimated error-bar of about $0.001 \mathrm{eV} /$ atom. Finally, the second-order elastic constants were determined using the stress-strain method [56].

\section{Results}

The first type of studied nanocomposite containing transition-metal disilicides is visualized in Figure 1a. $\mathrm{WSi}_{2}$ and $\mathrm{MoSi}_{2}$, which crystallize in the tetragonal $\mathrm{C} 11_{b}$ structure, form a coherent nanocomposite where two conventional cells of each materials are stacked one on top of the other along the [001] direction (the interfaces are perpendicular to this direction) and alternate. It should be emphasized that, due to the periodic boundary conditions, which are applied to all nanocomposites in our calculations, the simulated nanocomposites form so-called superlattices [57-78] when the atomic planes continue from one phase into another.

(a)

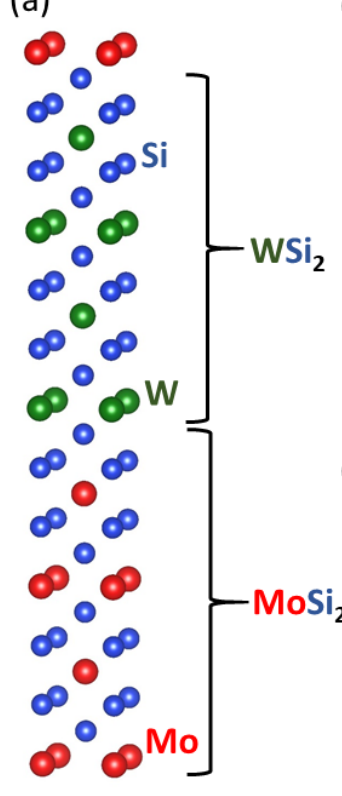

(b)

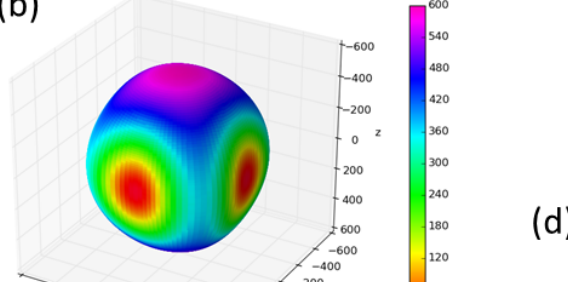

(d)

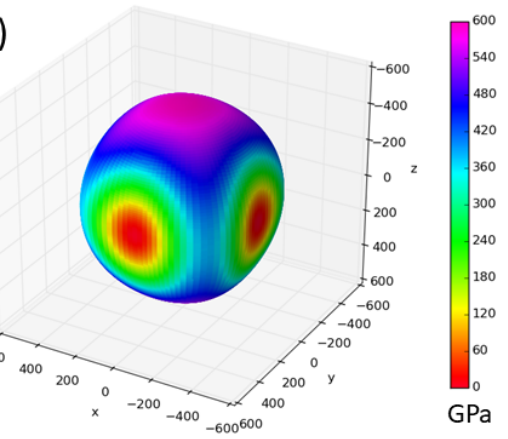

Figure 1. Visualization of a $\mathrm{WSi}_{2} / \mathrm{MoSi}_{2}$ nanocomposite (a superlattice) with the stacking along (and the interfaces perpendicular to) the [001] direction within the $\mathrm{C} 11_{b}$ lattice (a) accompanied with directional dependences of the Young's modulus of bulk $\mathrm{WSi}_{2}(\mathbf{b})$, bulk $\mathrm{MoSi}_{2}$ (c) and the composite $\mathrm{WSi}_{2} / \mathrm{MoSi}_{2}$ (d) formed out of them. The parts (b-d) were visualized by the SC-EMA [79-81] library (scema.mpie.de) based on ab initio computed elastic constants.

As seen in Table 1, both disilicides have very similar lattice parameters $a$ and $c$ describing their tetragonal structure and also quite similar elastic properties. Our theoretical values are in excellent agreement with both experimental data and previous calculations. The elasticity of bulk phases is conveniently visualized in Figure $1 b, c$ in the form of directional dependences of the Young's modulus. The values for this composite with an equal amount of both phases are listed in Table 1 at the line for the composition $\left(\mathrm{WSi}_{2}\right)_{4}\left(\mathrm{MoSi}_{2}\right)_{4}$. 
Table 1. Calculated structural characteristics and elastic constants of bulk $\mathrm{MoSi}_{2}$ and $\mathrm{WSi}_{2}$ as well as of their composite $\mathrm{MoSi}_{2} / \mathrm{WSi}_{2}$ with the stacking along (and the interfaces perpendicular to) the [001] direction within the $\mathrm{C} 11_{b}$ lattice. The computed values are complemented by experimental data from the literature. As far as the lattice parameters $a$ and $c$ of the $\mathrm{C} 11_{b}$ structure are concerned, the values for the $c$ lattice parameters of the nanocomposites are marked by the symbol of an asterisk* because they are divided by a factor of 4 to be compared with the values for the bulk unit cells of the individual constituents (bulk MoSi 2 and WSi ${ }_{2}$ ). The simulated nanocomposites are shown in Figure 2 and, specifically for the equal amount of both phases, in Figure 1a. Experimental elastic constants of $\mathrm{MoSi}_{2}$ and WSi 2 were taken from Refs. [82,83].

\begin{tabular}{|c|c|c|c|c|c|c|c|c|}
\hline Composition & $\begin{array}{c}a \\
(\AA)\end{array}$ & $\begin{array}{c}c \\
(\AA)\end{array}$ & $\begin{array}{c}C_{11} \\
(\mathrm{GPa})\end{array}$ & $\begin{array}{c}C_{12} \\
(\mathrm{GPa})\end{array}$ & $\begin{array}{c}C_{13} \\
(\mathrm{GPa})\end{array}$ & $\begin{array}{c}C_{33} \\
(\mathrm{GPa})\end{array}$ & $\begin{array}{c}C_{44} \\
(\mathrm{GPa})\end{array}$ & $\begin{array}{c}C_{66} \\
\text { (GPa) }\end{array}$ \\
\hline \multirow[t]{2}{*}{$\mathrm{MoSi}_{2}$} & 3.176 & 7.781 & 428 & 125 & 101 & 537 & 208 & 207 \\
\hline & 3.202 [83] & $7.855[83]$ & $417.0[82]$ & $104.2[82]$ & 83.8 [82] & 514.5 [82] & 204.2 [82] & $193.6[82]$ \\
\hline$\left(\mathrm{WSi}_{2}\right)_{1} /\left(\mathrm{MoSi}_{2}\right)_{7}$ & 3.178 & $7.782 *$ & 433 & 126 & 101 & 542 & 210 & 209 \\
\hline$\left(\mathrm{WSi}_{2}\right)_{2} /\left(\mathrm{MoSi}_{2}\right)_{6}$ & 3.180 & $7.781 *$ & 437 & 127 & 102 & 546 & 210 & 210 \\
\hline$\left(\mathrm{WSi}_{2}\right)_{3} /\left(\mathrm{MoSi}_{2}\right)_{5}$ & 3.181 & $7.781 *$ & 440 & 127 & 102 & 551 & 211 & 212 \\
\hline$\left(\mathrm{WSi}_{2}\right)_{4} /\left(\mathrm{MoSi}_{2}\right)_{4}$ & 3.183 & $7.780 *$ & 444 & 127 & 103 & 555 & 212 & 213 \\
\hline$\left(\mathrm{WSi}_{2}\right)_{5} /\left(\mathrm{MoSi}_{2}\right)_{3}$ & 3.185 & $7.780 *$ & 447 & 127 & 103 & 560 & 212 & 214 \\
\hline$\left(\mathrm{WSi}_{2}\right)_{6} /\left(\mathrm{MoSi}_{2}\right)_{2}$ & 3.186 & $7.780 *$ & 450 & 128 & 106 & 565 & 213 & 216 \\
\hline$\left(\mathrm{WSi}_{2}\right)_{7} /\left(\mathrm{MoSi}_{2}\right)_{1}$ & 3.188 & $7.780 *$ & 453 & 128 & 106 & 570 & 213 & 217 \\
\hline \multirow[t]{2}{*}{$\mathrm{WSi}_{2}$} & 3.188 & 7.778 & 456 & 131 & 105 & 576 & 214 & 217 \\
\hline & $3.211[83]$ & 7.835 [83] & $442.8[82]$ & $121.7[82]$ & 81.0 [82] & $552.3[82]$ & 211.6 [82] & $217.5[82]$ \\
\hline
\end{tabular}


As a consequence of the similarity of the elastic constants of both constituents, the overall elastic properties of their nanocomposites are quite similar, too.
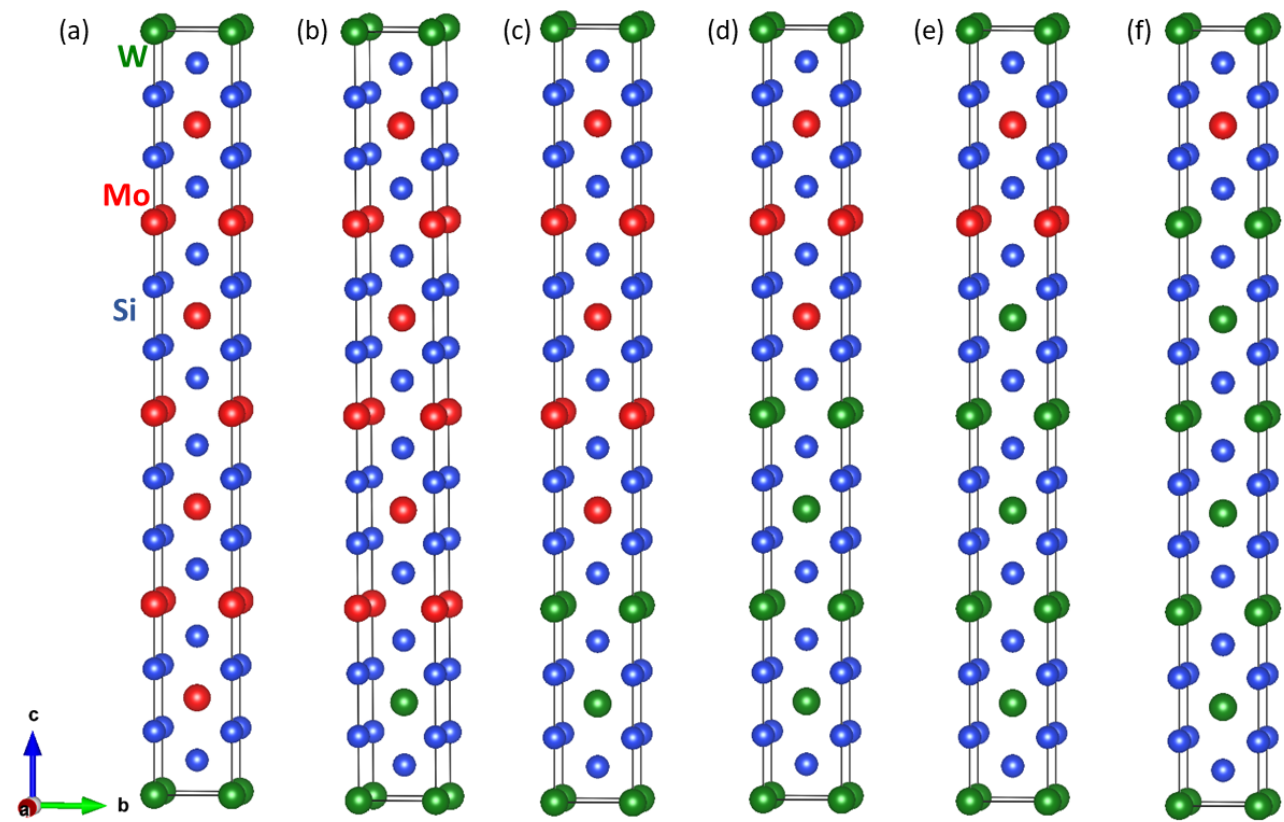

Figure 2. Schematic visualization of supercells modeling various nanocomposites with the stacking along (and the interfaces perpendicular to) the [001] direction. The mutual ratio of the constituents varies from 1:7, i.e., $\left(\mathrm{WSi}_{2}\right)_{1}\left(\mathrm{MoSi}_{2}\right)_{7}$, in the case of sub-figure (a), via 2:6 (b) and 3:5 (c) further for the opposite ratios 5:3 (d) and 6:2 (e) to 7:1, i.e., $\left(\mathrm{WSi}_{2}\right)_{7}\left(\mathrm{MoSi}_{2}\right)_{1}$, in the case of sub-figure (f).

Next, we evaluated the interface energy of the nanocomposites according to the formula:

$$
\gamma\left(\left(\mathrm{WSi}_{2}\right)_{m} /\left(\mathrm{MoSi}_{2}\right)_{n}\right)=\frac{E\left(\left(\mathrm{WSi}_{2}\right)_{m} /\left(\mathrm{MoSi}_{2}\right)_{n}\right)-m \cdot E\left(\mathrm{WSi}_{2}\right)-n \cdot E\left(\mathrm{MoSi}_{2}\right)}{(2 \cdot A)}
$$

using the energy $E\left(\left(\mathrm{WSi}_{2}\right)_{m} /\left(\mathrm{MoSi}_{2}\right)_{n}\right)$ of the supercell modeling the nanocomposite $\left(\mathrm{WSi}_{2}\right)_{m} /\left(\mathrm{MoSi}_{2}\right)_{n}$, which contains $m$ formula units of $\mathrm{WSi}_{2}$ and $n$ formula units of $\mathrm{MoSi}_{2}$, the energies of bulk phases of each constituent $E\left(\mathrm{WSi}_{2}\right)$ and $E\left(\mathrm{MoSi}_{2}\right)$ and the area of the interface $A$. Importantly, very probably due to the similarity of both constituents, the interface energy was found to be ultra low, essentially zero within the error bar of our calculations, i.e., the energy differences in Equation (1) are smaller than $0.001 \mathrm{eV} /$ atom and the interface energies are then smaller than about $0.005 \mathrm{~J} / \mathrm{m}^{2}$.

To examine how the ultra-low interface energies depend on the width of the layers containing individual constituents within the nanocomposite as well as on the ratio of amount of both materials, we simulated a series of seven other superlattices with varying width of the constituents, as visualized in Figure 2. The calculated structural and elastic parameters are summarized in Table 1. The lattice parameter $a$ increased quite monotonously from the value calculated for bulk $\mathrm{MoSi}_{2}$ to that obtained for bulk $\mathrm{WSi}_{2}$. The changes of the lattice parameter $c$ are much smaller because the values found for bulk $\mathrm{MoSi}_{2}$ and $\mathrm{WSi}_{2}$ are only very slightly different. Rather monotonous changes appear also for the elastic constants with all of them increasing when increasing the amount of elastically stiffer $\mathrm{WSi}_{2}$. Importantly, all the studied nanocomposites have again ultra low interface energies, which are essentially zero within the error-bar of our calculations. Next, as seen in the Appendix, the ultra low interface energies were nearly independent of the crystallographic orientation of the interface. 
After examining the $\mathrm{WSi}_{2} / \mathrm{MoSi}_{2}$ nanocomposites, which were experimentally reported to exist, we next drew our attention to another class of nanocomposites containing transition-metal disilicides, which were structurally and elastically very similar. The studied $\mathrm{TaSi}_{2}$ and $\mathrm{NbSi}_{2}$ crystallize in the hexagonal C40 structure and, therefore, we simulated a superlattice based on this structure (see Figure 3).
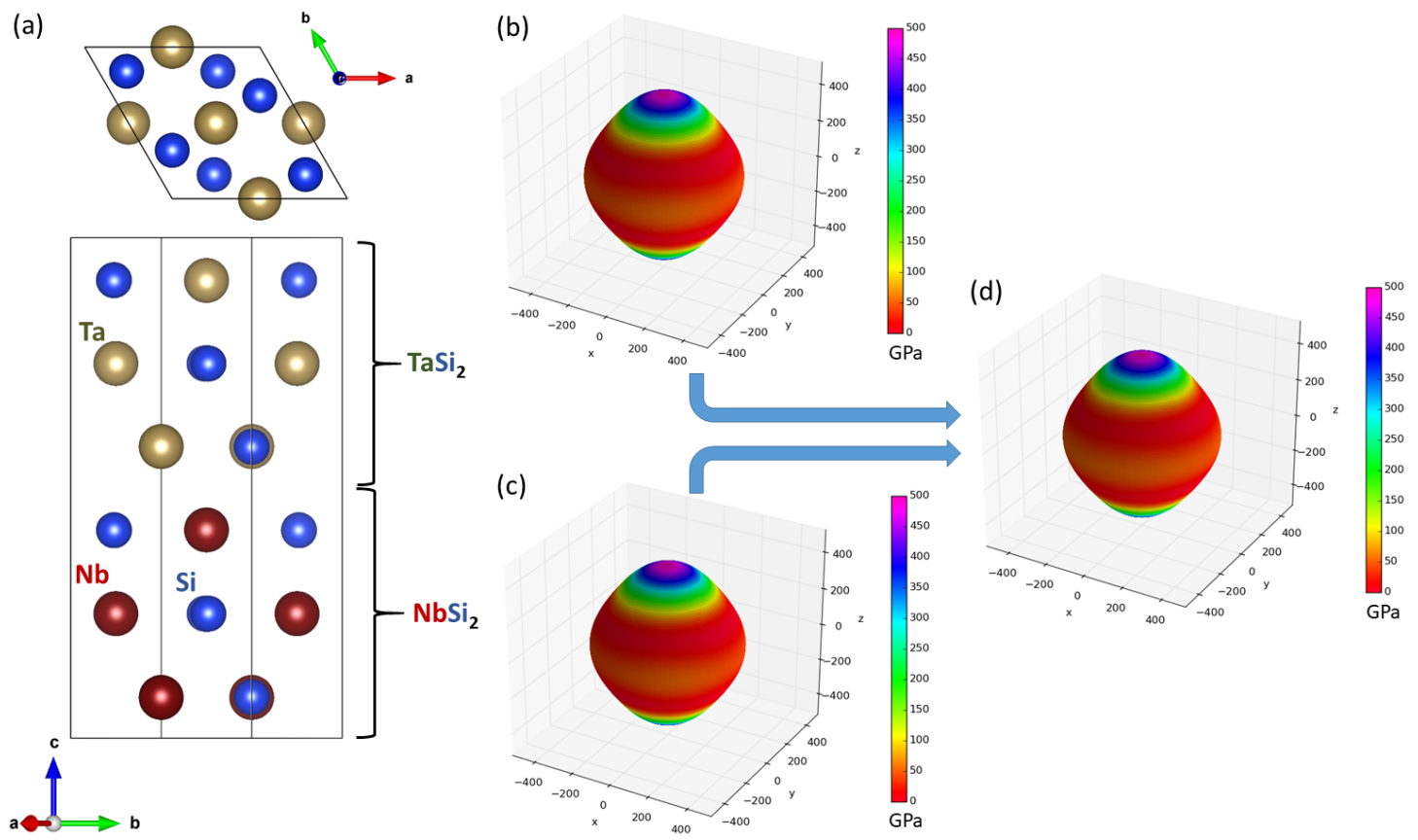

Figure 3. A top-view and a side-view of the computational supercell used in our calculations as a model of $\mathrm{TaSi}_{2} / \mathrm{NbSi}_{2}$ nanocomposite (a superlattice) with the stacking along (and the interfaces perpendicular to) the [0001] direction within the C40 lattice (a) accompanied with directional dependences of the Young's modulus of bulk $\mathrm{TaSi}_{2}(\mathbf{b})$, bulk $\mathrm{NbSi}_{2}$ (c) and their composite $\mathrm{TaSi}_{2} / \mathrm{NbSi}_{2}$ (d).

The nanocomposites have the interfaces perpendicular to the [0001] crystallographic direction. The lattice parameters $a$ and $c$ and elastic constants of both constituents in their bulk phases are summarized in Table 2. Our theoretical values are in an excellent agreement with both experimental data and previous calculations. Both disilicides have all the parameters very similar. The elasticity of bulk phases is conveniently visualized in Figure $3 b, c$ in the form of directional dependences of the Young's modulus. As the elastic properties are quite similar, the elasticity of the studied nanocomposite is not too different from that of the constituting phases (see Figure 3d). Importantly, the interface energy is ultra low for this superlattice, again zero within the error-bar of our calculations.

Similar to the case of the $\mathrm{WSi}_{2} / \mathrm{MoSi}_{2}$ nanocomposites studied above, we examined how the ultra-low interface energies depend on the molar ratio of the constituting phases as well as on the width of the phases forming the superlattice (see Figure 4). We performed our calculations for a series of six other nanocomposites with different ratio of the $\mathrm{TaSi}_{2}$ and $\mathrm{NbSi}_{2}$ (see Figure $4 \mathrm{a}-\mathrm{f}$ ). Out of the six calculated superlattices shown in Figure 4, those shown in Figure 4c,d have the same ratio of the amount of both materials but a higher number of internal interfaces, six and four, respectively.

When evaluating the interface energies, they were again found to be ultra low, namely zero within the error-bar of our calculations. The lattice parameters $a$ and $c$ of the C40-based structure are concerned were rather monotonously increasing from their lower values in $\mathrm{TaSi}_{2}$ to higher values in $\mathrm{NbSi}_{2}$. In contrast to this trend, the elastic constants rather monotonously decreased from their higher values in $\mathrm{TaSi}_{2}$ to lower values in $\mathrm{NbSi}_{2}$. 
Table 2. Calculated structural characteristics and elastic constants of bulk $\mathrm{TaSi}_{2}$ and $\mathrm{NbSi}_{2}$ as well as of their nanocomposites $\mathrm{TaSi}_{2} / \mathrm{NbSi}_{2}$ with the stacking along (and the interfaces perpendicular to) the [0001] direction within the C40 lattice. The computed values are complemented by both experimental data as well as by other theoretical results from literature. As far as the lattice parameters $a$ and $c$ of the C40 structure are concerned, the values of the lattice parameter $c$ for the nanocomposites are marked by an asterisk * because they are divided by factor of 2 to be compared with the values for the bulk unit cells of the individual constituents (bulk $\mathrm{TaSi}_{2}$ and $\mathrm{NbSi}_{2}$ ). Experimental elastic constants of $\mathrm{TaSi}_{2}$ and $\mathrm{NbSi}_{2}$ were taken from Ref. [84] and theoretical ones from Refs. [85,86].

\begin{tabular}{|c|c|c|c|c|c|c|c|}
\hline Composition & $\begin{array}{c}a \\
(\AA)\end{array}$ & $\begin{array}{c}c \\
(\AA)\end{array}$ & $\begin{array}{c}C_{11} \\
(\mathrm{GPa})\end{array}$ & $\begin{array}{c}C_{12} \\
(\mathrm{GPa})\end{array}$ & $\begin{array}{c}C_{13} \\
(\mathrm{GPa})\end{array}$ & $\begin{array}{c}C_{33} \\
(\mathrm{GPa})\end{array}$ & $\begin{array}{c}C_{44} \\
(\mathrm{GPa})\end{array}$ \\
\hline \multirow[t]{4}{*}{$\mathrm{TaSi}_{2}$} & 4.736 & 6.530 & 394 & 85 & 101 & 487 & 143 \\
\hline & $4.77[84]$ & $6.55[84]$ & $375.3[84]$ & $78.4[84]$ & $90.1[84]$ & $467.7[84]$ & $143.7[84]$ \\
\hline & $4.731[85]$ & $6.501[85]$ & $392.2[85]$ & $78.3[85]$ & $98.2[85]$ & $484.6[85]$ & $148.8[85]$ \\
\hline & - & - & $351.0[86]$ & $84.0[86]$ & $73.0[86]$ & $461.0[86]$ & $123.0[86]$ \\
\hline$\left(\mathrm{NbSi}_{2}\right)_{1} /\left(\mathrm{TaSi}_{2}\right)_{5}$-Figure $4 \mathrm{a}$ & 4.739 & $6.534 *$ & 392 & 84 & 99 & 483 & 143 \\
\hline$\left(\mathrm{NbSi}_{2}\right)_{2} /\left(\mathrm{TaSi}_{2}\right)_{4}$-Figure $4 \mathrm{~b}$ & 4.742 & $6.539 *$ & 390 & 83 & 98 & 479 & 142 \\
\hline$\left(\mathrm{NbSi}_{2}\right)_{3} /\left(\mathrm{TaSi}_{2}\right)_{3}$-Figure 3a & 4.745 & $6.543 *$ & 387 & 82 & 96 & 475 & 142 \\
\hline$\left(\mathrm{NbSi}_{2}\right)_{3} /\left(\mathrm{TaSi}_{2}\right)_{3}$-Figure $4 \mathrm{c}$ & 4.745 & $6.543 *$ & 387 & 82 & 96 & 476 & 142 \\
\hline$\left(\mathrm{NbSi}_{2}\right)_{3} /\left(\mathrm{TaSi}_{2}\right)_{3}$-Figure $4 \mathrm{~d}$ & 4.745 & $6.543 *$ & 388 & 82 & 96 & 476 & 142 \\
\hline$\left(\mathrm{NbSi}_{2}\right)_{4} /\left(\mathrm{TaSi}_{2}\right)_{2}$-Figure $4 \mathrm{e}$ & 4.748 & $6.547 *$ & 385 & 81 & 95 & 472 & 142 \\
\hline$\left(\mathrm{NbSi}_{2}\right)_{5} /\left(\mathrm{TaSi}_{2}\right)_{1}$-Figure $4 \mathrm{f}$ & 4.751 & $6.551 *$ & 383 & 80 & 94 & 469 & 141 \\
\hline \multirow[t]{4}{*}{$\mathrm{NbSi}_{2}$} & 4.754 & 6.555 & 380 & 79 & 92 & 465 & 141 \\
\hline & $4.79[84]$ & $6.59[84]$ & $380.2[84]$ & $75.9[84]$ & $88.3[84]$ & $468.0[84]$ & $145.3[84]$ \\
\hline & $4.747[85]$ & $6.529[85]$ & $378.9[85]$ & $73.0[85]$ & $90.2[85]$ & $462.5[85]$ & $144.6[85]$ \\
\hline & - & - & $344.0[86]$ & $85.0[86]$ & $69.0[86]$ & $456.0[86]$ & $115.0[86]$ \\
\hline
\end{tabular}




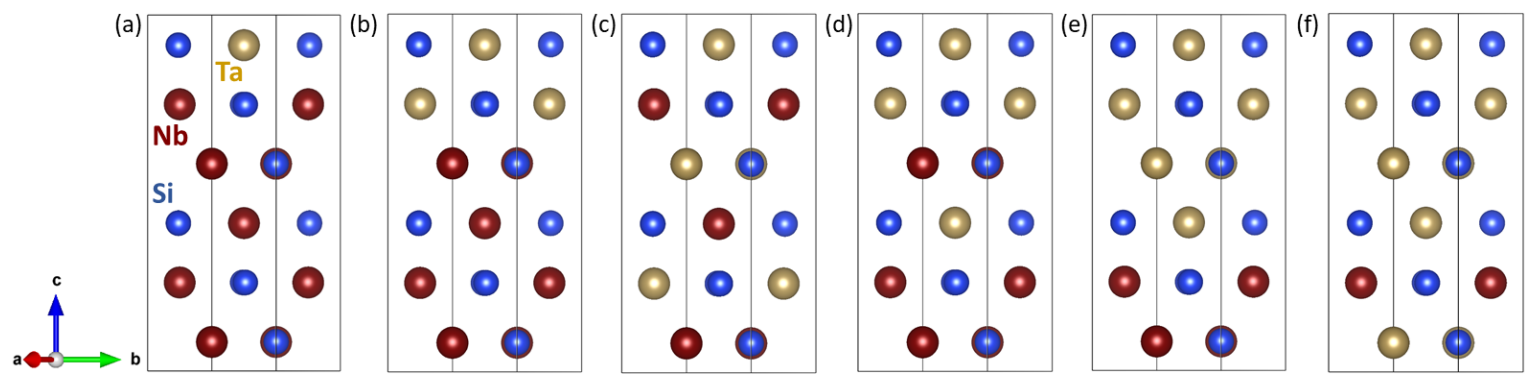

Figure 4. Schematic visualization of simulated $\mathrm{NbSi}_{2} / \mathrm{TaSi}_{2}$ nanocomposites with the stacking along (and the interfaces perpendicular to) the [0001] direction. The mutual ratio of the amount of constituents varies from 1:5, i.e., $\left(\mathrm{NbSi}_{2}\right)_{1}\left(\mathrm{TaSi}_{2}\right)_{5}$ in the case of (a) via 2:4 (b), 3:3 (c,d) to 4:2 (e) and 5:1, i.e., $\left(\mathrm{NbSi}_{2}\right)_{5}\left(\mathrm{TaSi}_{2}\right)_{1}$ in the case of $(\mathbf{f})$. Variants shown in $(\mathbf{c}, \mathbf{d})$ have an equal amount of both constituting phases (similar to the case of Figure 3a) but a different arrangement of atomic layers. Consequently, there is a higher number of internal interfaces (6 and 4 in the case of (c,d), respectively) and the layers with different constituents have different widths.

The last systems studied here is that containing two different phases from the binary iron-aluminium system, in particular, an ordered $\mathrm{Fe}_{3} \mathrm{Al}$ intermetallic compound crystallizing in the $\mathrm{D}_{3}$ structure and a disordered solid solution of 18.75 at. $\%$ of $\mathrm{Al}$ with a body-centered cubic (bcc) ferromagnetic (FM) matrix, so-called $\alpha$-or B2 phase. The structure of the former was is derived from the bcc lattice and, therefore, both materials structurally match each other. The studied nanocomposite is schematically visualized in Figure $5 \mathrm{a}$. $\mathrm{Fe}_{3} \mathrm{Al}$ was modeled by a 16-atom conventional cell depicted in the upper part of in Figure $5 \mathrm{a}$. The $\alpha$-phase represents a challenge for quantum-mechanical calculations because it lacks any long-range periodicity. We used a 16-atom supercell with atoms distributed according to so-called special quasi-random structure (SQS) concept.
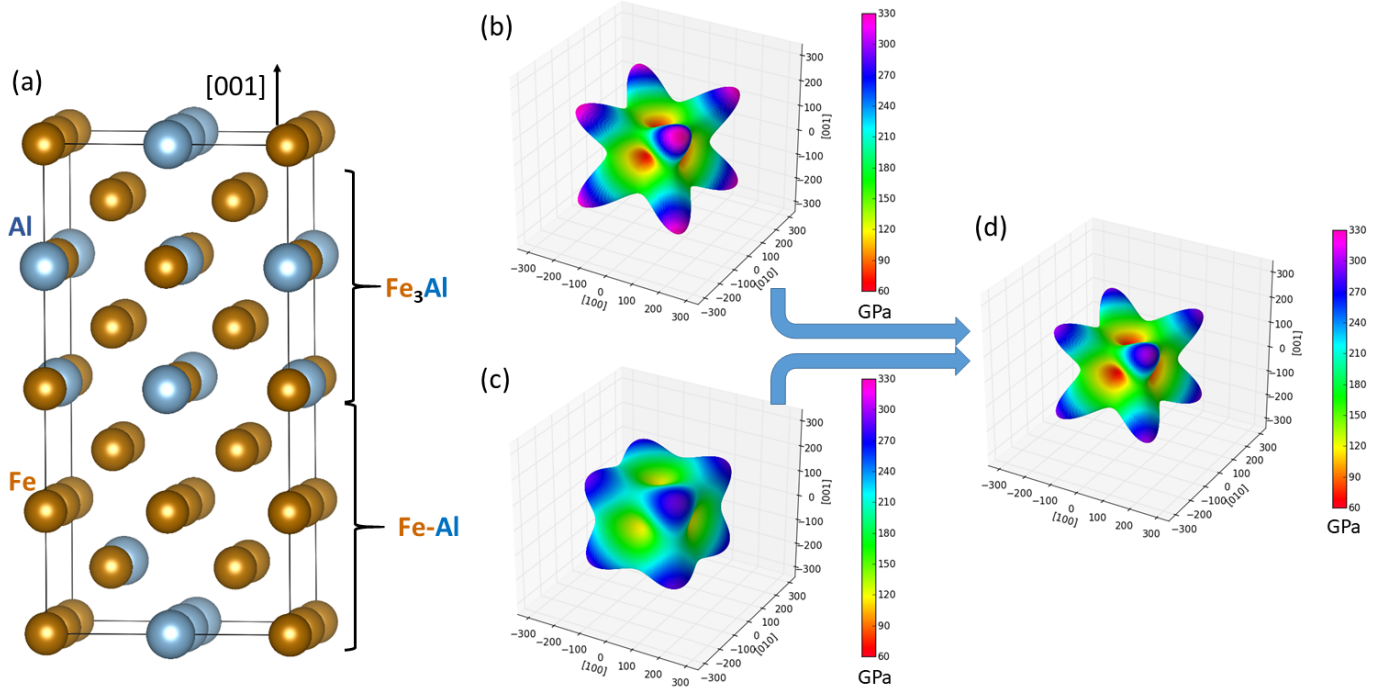

Figure 5. Visualization of a $\mathrm{Fe}_{3} \mathrm{Al} / \mathrm{Fe}-\mathrm{Al}$ nanocomposite (a superlattice) with the stacking along (and the interfaces perpendicular to) the [001] direction (a) accompanied with directional dependences of the Young's modulus of bulk $\mathrm{Fe}_{3} \mathrm{Al}$ (b), bulk $\mathrm{Fe}-\mathrm{Al}$ (c) and the nanocomposite $\mathrm{Fe}_{3} \mathrm{Al} / \mathrm{Fe}-\mathrm{Al}$ (d) formed out of them. Parts (b-d) were visualized by the SC-EMA [79-81] library (scema.mpie.de) based on ab initio computed elastic constants.

The nanocomposite was formed by stacking the $\mathrm{Fe}_{3} \mathrm{Al}$ on top of the $\alpha$-phase along the [001] direction (the interfaces are perpendicular to this direction). In contrast to the above-discussed cases of 
superlattices formed by pairs of ordered transition-metal disilicides, when the both interfaces in the simulation supercell were identical, the supercells modeling the Fe-Al-based nanocomposites have different interfaces due to different distribution of atoms in the disordered $\alpha$-phase. The interface energies were then averaged values related to the two interfaces. As another difference between the pairs of structurally and elastically nearly identical disilicides discussed above, the two constituting phases have clearly distinguishable elastic properties. Again, they are conveniently visualized in the form of directional dependences of the Young's modulus in Figure $5 b, c$ for the $\mathrm{Fe}_{3} \mathrm{Al}$ and the $\mathrm{Fe}-\mathrm{Al} \alpha$-phase, respectively. The calculated values of elastic constants for $\mathrm{Fe}_{3} \mathrm{Al}$ compound are $C_{11}=$ $211 \mathrm{GPa}, C_{12}=161 \mathrm{GPa}$ and $C_{44}=139 \mathrm{GPa}$. The elastic constants calculated for the disordered Fe-Al $\alpha$-phase were projected onto a set of elastic constants possessing a cubic symmetry according to the rigorous mathematical theory by Moakher and Norris [87]. Similar concepts are often used in case of systems with any form of disorder (see, e.g., Refs. [59,88-91]). The resulting cubic-symmetry elastic constants are $C_{11}=217 \mathrm{GPa}, C_{12}=131 \mathrm{GPa}$ and $C_{44}=120 \mathrm{GPa}$. Both phases exhibit $\langle 001\rangle$ directions as elastically soft and $\langle 111\rangle$ directions as elastically hard (i.e., with the minimum and maximum values of the Young's modulus, respectively). The $\mathrm{Fe}_{3} \mathrm{Al}$ is also apparently elastically more anisotropic. The overall elasticity of their composite is then shown in Figure $5 \mathrm{~d}$.
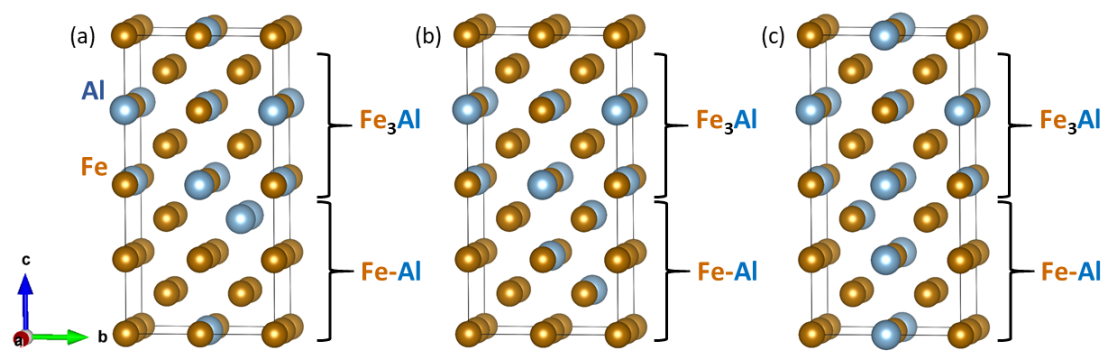

(d)
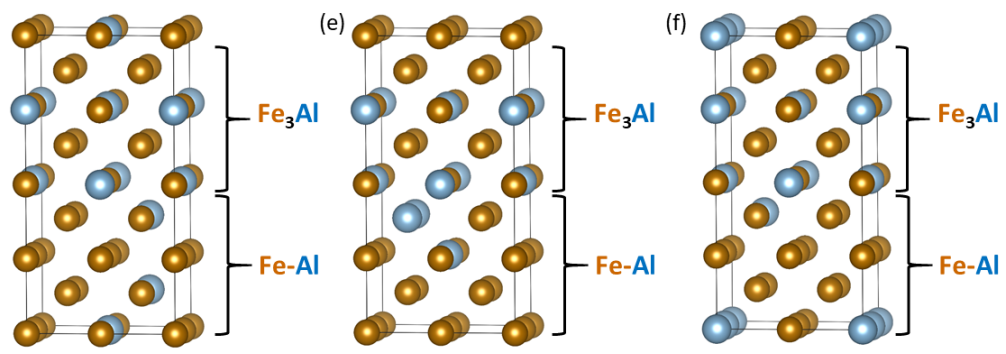

Figure 6. Schematic visualizations of different computed $\mathrm{Fe}_{3} \mathrm{Al} / \mathrm{Fe}-\mathrm{Al}$ nanocomposites. The computed variants shown in sub-figures (a-f) differ by the distribution of atoms in the disordered Fe-Al phase.

Importantly, the interface energy was found to be ultra low again, only $0.005 \mathrm{~J} / \mathrm{m}^{2}$, which represents an energy difference appearing in Equation ((1)) smaller than $0.001 \mathrm{eV} /$ atom, i.e., within the error-bar of our calculations. To determine an impact of distribution of atoms in the disordered $\mathrm{Fe}-\mathrm{Al} \alpha$-phase on the interface energies, we performed a series of six additional calculations for supercells which have the same stoichiometry but differ in distributions of atoms in the $\mathrm{Fe}-\mathrm{Al} \alpha$-phase (see Figure 6). In fact, the structure of coordination shells of atoms remain the same. For example, considering the $\mathrm{Al}$ atoms, their distribution in the part corresponding to the $\mathrm{Fe}-\mathrm{Al} \alpha$-phase in the structural variants in Figure 6 are the same but the part of the supercell corresponding to the Fe-Al $\alpha$-phase is either rotated and/or the atomic planes are permuted. As far as the latter process is concerned, if the atomic planes perpendicular to the [001] direction in the $\alpha$-phase part of Figure 5a would be numbered 1, 2, 3, 4, then by a permutation is meant, e.g., an arrangement 2, 3, 4, 1. Importantly, if being in a single-phase bulk, such permutation of atomic planes within the periodically repeated cell or rotations of the whole cell would not change the energy because the position of the origin 
of coordinates (and the attached coordinate frame) can be arbitrarily shifted with respect to the crystal lattice.

Table 3. Calculated elastic constants of $\mathrm{Fe}_{3} \mathrm{Al} / \mathrm{Fe}-\mathrm{Al}$ nanocomposites with the stacking along (and the interfaces perpendicular to) the [001] direction. The nanocomposites are visualized in Figure 6.

\begin{tabular}{|c|c|c|c|c|c|c|c|c|c|}
\hline Variant & $\begin{array}{c}C_{11} \\
(\mathrm{GPa})\end{array}$ & $\begin{array}{c}C_{12} \\
(\mathrm{GPa})\end{array}$ & $\begin{array}{c}C_{13} \\
\text { (GPa) }\end{array}$ & $\begin{array}{c}C_{22} \\
(\mathrm{GPa})\end{array}$ & $\begin{array}{c}C_{23} \\
(\mathrm{GPa})\end{array}$ & $\begin{array}{c}C_{33} \\
(\mathrm{GPa})\end{array}$ & $\begin{array}{c}C_{44} \\
(\mathrm{GPa})\end{array}$ & $\begin{array}{l}C_{55} \\
(\mathrm{GPa})\end{array}$ & $\begin{array}{c}C_{66} \\
(\mathrm{GPa})\end{array}$ \\
\hline $\mathrm{Fe}_{3} \mathrm{Al} / \mathrm{Fe}-\mathrm{Al}$ Figure $6 \mathrm{a}$ & 188 & 143 & 134 & 201 & 139 & 199 & 120 & 126 & 124 \\
\hline $\mathrm{Fe}_{3} \mathrm{Al} / \mathrm{Fe}-\mathrm{Al}$ Figure $6 \mathrm{~b}$ & 186 & 134 & 142 & 185 & 141 & 199 & 123 & 123 & 123 \\
\hline $\mathrm{Fe}_{3} \mathrm{Al} / \mathrm{Fe}-\mathrm{Al}$ Figure $6 \mathrm{c}$ & 197 & 146 & 145 & 196 & 145 & 184 & 129 & 129 & 124 \\
\hline $\mathrm{Fe}_{3} \mathrm{Al} / \mathrm{Fe}-\mathrm{Al}$ Figure $6 \mathrm{~d}$ & 200 & 151 & 143 & 199 & 143 & 200 & 125 & 125 & 122 \\
\hline $\mathrm{Fe}_{3} \mathrm{Al} / \mathrm{Fe}-\mathrm{Al}$ Figure $6 \mathrm{e}$ & 183 & 135 & 138 & 189 & 136 & 202 & 117 & 124 & 123 \\
\hline $\mathrm{Fe}_{3} \mathrm{Al} / \mathrm{Fe}-\mathrm{Al}$ Figure $6 \mathrm{f}$ & 175 & 141 & 137 & 189 & 145 & 200 & 121 & 126 & 127 \\
\hline
\end{tabular}

The situation is, on the other hand, different in nanocomposites because the interface represents a reference point not existing in the single-phase bulk. The calculated energies are covering a broader range: $0.055 \mathrm{~J} / \mathrm{m}^{2}$ (Figure $6 \mathrm{a}$ ), $0.021 \mathrm{~J} / \mathrm{m}^{2}$ (Figure $6 \mathrm{~b}$ ), $0.032 \mathrm{~J} / \mathrm{m}^{2}$ (Figure $6 \mathrm{c}$ ), $0.006 \mathrm{~J} / \mathrm{m}^{2}$ (Figure $6 \mathrm{~d}$ ), $0.139 \mathrm{~J} / \mathrm{m}^{2}$ (Figure 6e), and $0.014 \mathrm{~J} / \mathrm{m}^{2}$ (Figure $6 \mathrm{f}$ ). While this sensitivity on the atomic distribution is rather significant, the elastic properties of nanocomposites shown in Figure 6 are very similar. The computed values of elastic constants are summarized in Table 3.

As both phases appearing in the studied nanocomposites are magnetic, we further examined local magnetic moments of the iron atoms in configurations visualized in Figure 6a-f. The magnitude of local magnetic moments are shown in Figure 7 by the diameter of the spheres representing the Fe atoms. The lowest and the highest value $\left(1.8 \mu_{\mathrm{B}}\right.$ and $\left.2.44 \mu_{\mathrm{B}}\right)$ are explicitly mentioned in Figure $7 \mathrm{a}$ to demonstrate a scaling, by which the magnitude of the local magnetic moment is indicated by the diameter of the spheres. Importantly, the magnetic properties of the Fe atoms turned out to be very sensitive to the distribution of atoms (they are reduced when the $\mathrm{Al}$ atoms are nearby).
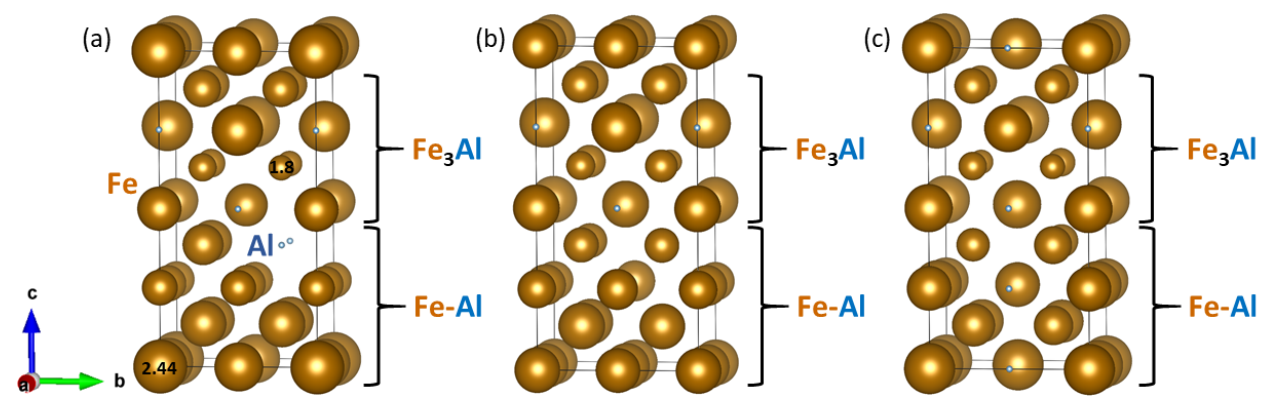

(d)

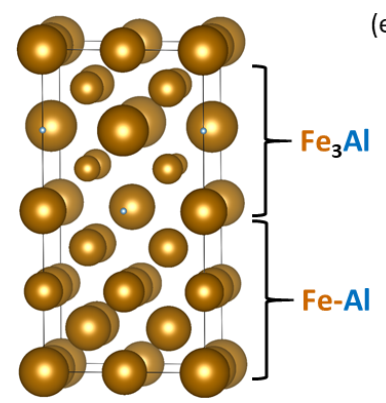

(e)

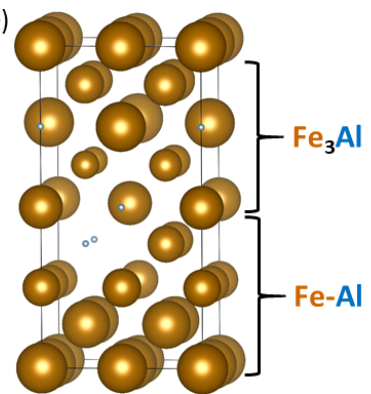

(f)

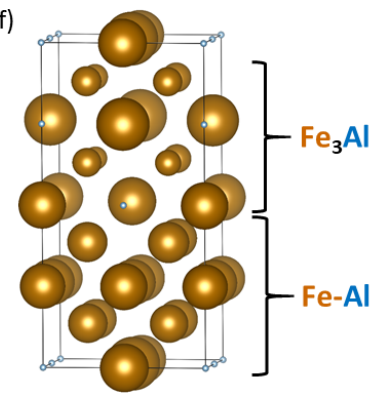

Figure 7. Calculated local magnetic moments of iron atoms (the magnitude is indicated by the diameter of the spheres representing the Fe atoms). The local magnetic moments shown in sub-figures $(\mathbf{a}-\mathbf{f})$ correspond to atomic distributions of nanocomposites visualized in sub-figures (a-f) of Figure 6, respectively. 


\section{Discussion}

The above-discussed ultra low interface energies in the $\mathrm{MoSi}_{2} / \mathrm{WSi}_{2}$ nanocomposites may also indicate that both constituents are prone to mixing even at the atomic level. Indeed, it seems that longer annealing times lead to formation of solid-solution phases rather than (nano)composites. For example, $\mathrm{MoSi}_{2} / \mathrm{WSi}_{2}$ powders are synthesized by means of self-propagating high temperature combustion in [92] but solid solutions of $\mathrm{MoSi}_{2} / \mathrm{WSi}_{2}$ and $\mathrm{Mo}_{5} \mathrm{Si}_{3} / \mathrm{W}_{5} \mathrm{Si}_{3}$ are found. In [93], it is also reported that it is hard to distinguish $\mathrm{MoSi}_{2}$ and $\mathrm{WSi}_{2}$ phases and $(\mathrm{W}, \mathrm{Mo}) \mathrm{Si}_{2}$ mainly in solid solution is found in Ref. [94]. The difficulties to distinguish $\mathrm{MoSi}_{2}$ and $\mathrm{WSi}_{2}$ Bragg peaks can be attributed to tetragonal $\mathrm{MoSi}_{2}$ and $\mathrm{WSi}_{2}$ phase having a long-range structure with very similar lattice constants ( $a$ is equal to $0.3202 \mathrm{~nm}$ and $0.3211, c$ amounts to $0.7855 \mathrm{~nm}$ and $0.7835 \mathrm{~nm}$, respectively) [83]. It is also confirmed that $\mathrm{MoSi}_{2} / \mathrm{WSi}_{2}$ solid solution powder with nanometric $(\mathrm{Mo}, \mathrm{W}) \mathrm{Si}_{2}$ structure forms via combustion synthesis method from the mechanical activated powder mixture [95].

To test the scenario of a random solid solution of Mo and $\mathrm{W}$ within a $\mathrm{C} 11_{b}$ lattice, we performed a series of calculations for supercells modeling these states (see Figure 8a-d). The corresponding enthalpies of mixing (evaluated with respect to the energy of $\mathrm{MoSi}_{2}$ and $\mathrm{WSi}_{2}$ as reference end-members) are shown in Figure $8 \mathrm{e}$ and all of them are between zero and $-0.001 \mathrm{eV} / \mathrm{atom}$, i.e., within the error-bar of our calculations and comparable to the energy differences obtained when simulating the $\mathrm{MoSi}_{2} / \mathrm{WSi}_{2}$ nanocomposites.

(a)

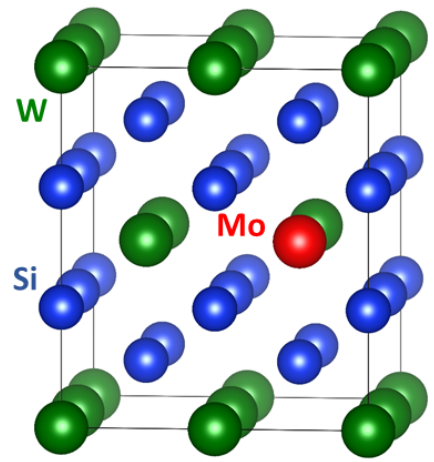

(d)

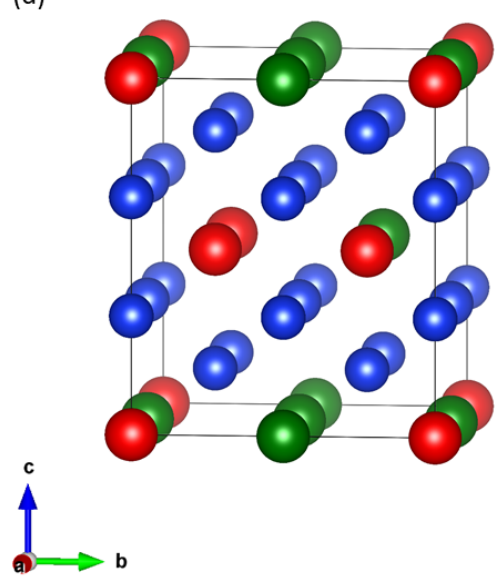

(b)

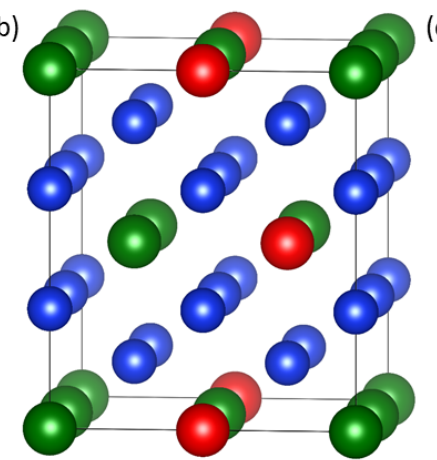

(e)

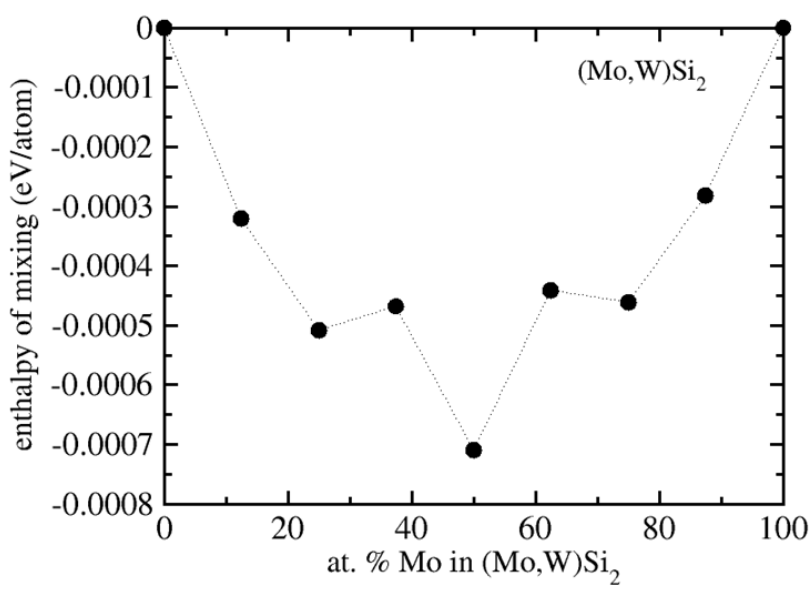

Figure 8. Schematic visualization of the supercells modeling random solid solutions of Mo and $\mathrm{W}$ within a $\mathrm{C} 11_{b}$ lattice in the case of Mo:W ratio equal to 1:7 (a), 2:6 (b), 3:5 (c), and 4:4 (d) together with the correspondingenthalpies of mixing (e). The supercells for the Mo:W ratios equal to 5:3, 6:2 and 7:1 were obtained by swapping Mo and $\mathrm{W}$ atoms in the supercells shown in sub-figures $(\mathbf{a}-\mathbf{c})$. The atoms in the 32-atom supercells $\left(2 \times 2 \times 1\right.$ multiple of 6-atom conventional cell of the $\mathrm{C} 11_{b}$ structure) were distributed according to the special quasi-random structure (SQS) concept [96]. 
The above-discussed competition between formation of two-phase nanocomposites on the one hand and single-phase solid solutions on the other hand probably explains why a suitable preparation route is still being searched for in the case of $\mathrm{TaSi}_{2} / \mathrm{NbSi}_{2}$ nanocomposites when $\mathrm{Nb}$ solubility in $\mathrm{TaSi}_{2}$ extremely large [97]. Our results related to the $\mathrm{TaSi}_{2} / \mathrm{NbSi}_{2}$ nanocomposites are intended as a motivation for future studies of this interesting system.

\section{Conclusions}

We performed a first-principles study of structural, thermodynamic and elastic properties of nanocomposites exhibiting ultra low or low interface energies. As examples of systems with predominantly covalent interatomic bonds, we studied two combinations of transition-metal disilicides: (i) $\mathrm{MoSi}_{2} / \mathrm{WSi}_{2}$ nanocomposites with individual constituents crystallizing in the tetragonal $\mathrm{C} 11_{b}$ structure; and (ii) $\mathrm{TaSi}_{2} / \mathrm{NbSi}_{2}$ with the two components crystallizing in the hexagonal C40 structure. The constituents within each pair of materials exhibit very similar structural and elastic properties and we obtained ultra low (nearly zero) interface energy for their nanocomposites (within the error bar of our calculations, i.e., about $0.005 \mathrm{~J} / \mathrm{m}^{2}$ ). The interface energy was found to be nearly independent on the width of individual constituents within the nanocomposites and/or crystallographic orientation of the interfaces.

As an example of a magnetic system, a pair of metallic phases containing from the Fe-Al system with different atomic ordering was considered. In particular, we simulated coherent superlattices formed by an ordered $\mathrm{Fe}_{3} \mathrm{Al}$ intermetallic compound and a disordered $\mathrm{Fe}-\mathrm{Al}$ phase with 18.75 at.\% $\mathrm{Al}$, the $\alpha$-phase. Both constituents are structurally and elastically rather similar (but less than the two pairs of studied disilicides). To estimate the interface energy in the nanocomposite containing the disordered $\alpha$-phase, which lacks a long-range periodicity, we simulated seven different distributions of atoms in the $\alpha$-phase interfacing the $\mathrm{Fe}_{3} \mathrm{Al}$ intermetallic compound. The resulting interface energies were again either ultra low or low, from 0.005 to $0.139 \mathrm{~J} / \mathrm{m}^{2}$. While the impact of atomic distribution on the elastic properties was found insignificant, the local magnetic moments of the iron atoms sensitively depended on the type and the distribution of surrounding atoms.

Author Contributions: Conceptualization, M.F.; Methodology, D.H.; Resources, M.Š. and M.F.; Writing-Original Draft Preparation, M.F.; Writing—Review and Editing, D.H. and M.Š.; Visualization, M.F.; Supervision, M.Š.; Project Administration, M.Š. and M.F.; and Funding Acquisition, M.Šs. and M.F.

Funding: The authors acknowledge the Czech Science Foundation for the financial support received under the Project Nos. 16-24711S (M.Š.) and 17-22139S (M.F.). Additional resources were provided by the Academy of Sciences of the Czech Republic through the Fellowship of J. E. Purkyně (M.F.) and by the Ministry of Education, Youth and Sports of the Czech Republic under the Project CEITEC 2020, LQ1601 (M.Š). D.H. acknowledges financial support from the Austrian Science Fund (FWF), Project Number P30341-N36. The computational results presented have been achieved in part using the Vienna Scientific Cluster (VSC).

Acknowledgments: M.F. and M.Š. acknowledge the support from the Academy of Sciences of the Czech Republic (Institutional Project No. RVO:68081723) and from the Ministry of Education, Youth and Sports of the Czech Republic via the research infrastructure IPMINFRA, LM2015069. Computational resources were made available by the Ministry of Education, Youth and Sports of the Czech Republic under the Projects CESNET (Project No. LM2015042), CERIT-Scientific Cloud (Project No. LM2015085) and IT4Innovations National Supercomputer Center (Project No. LM2015070) within the program Projects of Large Research, Development and Innovations Infrastructures. Figures 1a, 2, 3a, 4, 5a, 6, 8a-d, and A1a,b were visualized using the VESTA package [98].

Conflicts of Interest: The authors declare no conflict of interest.

\section{Appendix A}

To analyze the dependence of the ultra-low interface energies in the $\mathrm{MoSi}_{2} / \mathrm{WSi}_{2}$ nanocomposites on the crystallographic orientation of the interface, we computed properties of two other superlattices with the interfaces perpendicular to the [010] and [110] directions, respectively. The corresponding supercells modeling these nanocomposites are shown in Figure A1a,b, respectively. The elastic properties of these superlattices are visualized in the form of directional dependences of the Young's 
modulus in Figure A1c,d. It is obvious that they are again very similar to each other and also very similar to that of the superlattice with the interfaces perpendicular to the [001] direction.

(a)

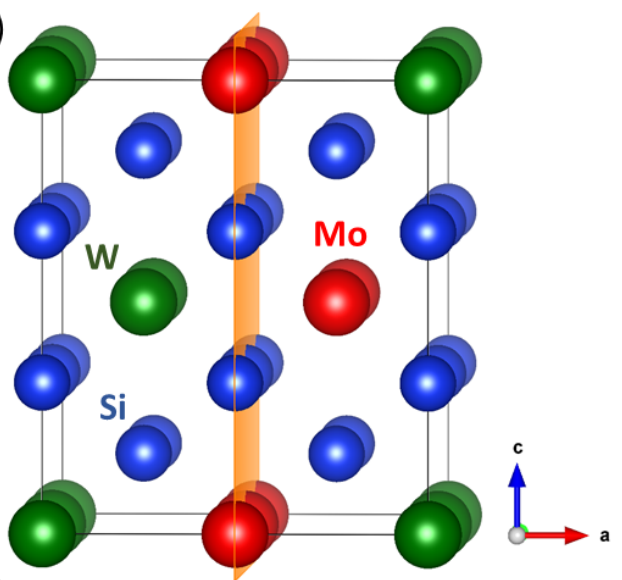

(c)

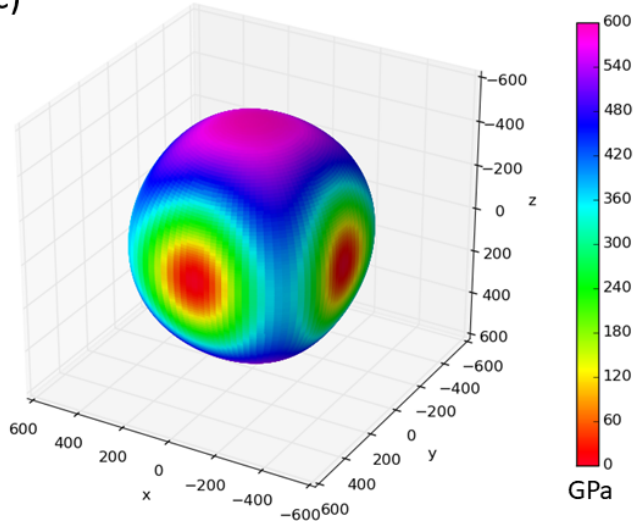

(b)

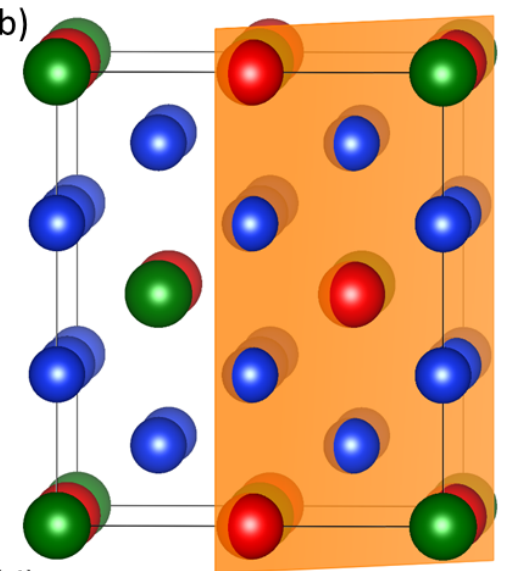

(d)

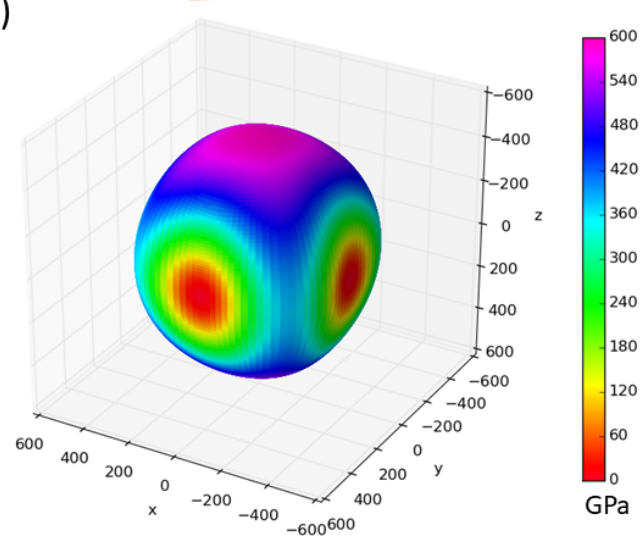

Figure A1. Schematics of computational supercells of $\mathrm{MoSi}_{2} / \mathrm{WSi}_{2}$ nanocomposites (superlattices) with the stacking along (and the interfaces perpendicular to) the [010] (a) and [110] (b) directions within the $\mathrm{C} 11_{b}$ lattice, respectively. The interface planes are marked by orange color. The calculated elastic constants for these superlattices are shown as directional dependences of the Young's modulus for the composite with the [010] stacking direction (c) as well as that with the [110] stacking direction (d). Parts (c,d) were visualized by the SC-EMA [79-81] library (scema.mpie.de) based on ab initio computed elastic constants.

\section{References}

1. Yamaguchi, M.; Inui, H.; Ito, K. High-temperature structural intermetallics. Acta Mater. 2000, 48, 307-322. [CrossRef]

2. Umakoshi, Y.; Nakano, T.; Kishimoto, K.; Furuta, D.; Hagihara, K.; Azuma, M. Strength and deformation mechanism of C40-based single crystal and polycrystalline silicides. Mater. Sci. Eng. A 1999, 261, 113-121. [CrossRef]

3. Petrovic, J.; Vasudevan, A. Key developments in high temperature structural silicides. Mater. Sci. Eng. A 1999, 261, 1-5. [CrossRef]

4. Inui, H.; Moriwaki, M.; Yamaguchi, M. Plastic deformation of single crystals of $\mathrm{VSi}_{2}$ and $\mathrm{TaSi}_{2}$ with the C40 structure. Intermetallics 1998, 6, 723-728. [CrossRef]

5. Zhou, Y.; Zhang, Z.; Jin, X.; Ye, G.; Liu, C. Fabrication and Composition Investigation of $\mathrm{WSi}_{2} / \mathrm{MoSi}_{2}$ Composite Powders Obtained by a Self-Propagating High-Temperature Synthesis Method. Arabian J. Sci. Eng. 2016, 41, 2583-2587. [CrossRef]

6. Deevi, S.C. Self-propagating high-temperature synthesis of molybdenum disilicide. J. Mater. Sci. 1991, 26, 3343-3353. [CrossRef] 
7. Ke, P.; Yi, M.; Ran, L. Reaction thermodynamics of $\mathrm{MoSi}_{2}-\mathrm{WSi}_{2}$ composites in the thermal explosion mode of SHS. Rare Met. Mater. Eng. 2006, 35, 554-558.

8. Zhang, H.; Chen, P.; Wang, M.; Liu, X. Room-temperature mechanical properties of $\mathrm{WSi}_{2} / \mathrm{MoSi}_{2}$ composites. Rare Met. 2002, 21, 304-307.

9. Chen, F.; Xu, J.; Liu, Y.; Cai, L. In situ reactive spark plasma sintering of $\mathrm{WSi} 2 / \mathrm{MoSi}_{2}$ composites. Ceram. Int. 2016, 42, 11165-11169. [CrossRef]

10. Zamani, S.; Bakhsheshi-Rad, H.R.; Kadir, M.R.A.; Shafiee, M.R.M. Synthesis and kinetic study of (Mo,W)Si $2-\mathrm{WSi}_{2}$ nanocomposite by mechanical alloying. J. Alloys Compd. 2012, 540, 248-259. [CrossRef]

11. Xu, J.; Wang, Y.; Weng, B.; Chen, F. Preparation and Characterization of $\mathrm{MoSi}_{2} / \mathrm{WSi}_{2}$ Composites from MASHSed Powder. Mater. Trans. 2015, 56, 313-316. [CrossRef]

12. Kattner, U.; Burton, B. Al-Fe (Aluminium-Iron). In Phase Diagrams of Binary Iron Alloys; Okamoto, H., Ed.; ASM International: Materials Park, OH, USA, 1993; pp. 12-28.

13. Sauthoff, G. Intermetallics; VCH Verlagsgesellschaft: Weinheim, Germany, 1995.

14. Liu, C.T.; Stringer, J.; Mundy, J.N.; Horton, L.L.; Angelini, P. Ordered intermetallic alloys: An assessment. Intermetallics 1997, 5, 579-596. [CrossRef]

15. Stoloff, N.S. Iron aluminides: Present status and future prospects. Mater. Sci. Eng. A 1998, 258, 1-14. [CrossRef]

16. Palm, M.; Inden, G.; Thomas, N. The Fe-Al-Ti system. J. Phase Equilib. 1995, 16, 209-222. [CrossRef]

17. Palm, M.; Lacaze, J. Assessment of the Al-Fe-Ti system. Intermetallics 2006, 14, 1291-1303. [CrossRef]

18. Palm, M.; Sauthoff, G. Deformation behaviour and oxidation resistance of single-phase and two-phase L2 1 -ordered Fe-Al-Ti alloys. Intermetallics 2004, 12, 1345-1359. [CrossRef]

19. Sundman, B.; Ohnuma, I.; Dupin, N.; Kattner, U.R.; Fries, S.G. An assessment of the entire Al-Fe system including D0(3) ordering. Acta Mater. 2009, 57, 2896-2908. [CrossRef]

20. Stein, F.; Palm, M. Re-determination of transition temperatures in the Fe-Al system by differential thermal analysis. Int. J. Mater. Res. 2007, 98, 580-588. [CrossRef]

21. Palm, M. Fe-Al materials for structural applications at high temperatures: Current research at MPIE. Int. J. Mater. Res. 2009, 100, 277-287. [CrossRef]

22. Watson, R.E.; Weinert, M. Transition-metal aluminide formation: Ti, V, Fe, and Ni aluminides. Phys. Rev. B 1998, 58, 5981-5988. [CrossRef]

23. Gonzales-Ormeno, P.; Petrilli, H.; Schon, C. Ab-initio calculations of the formation energies of BCC-based superlattices in the Fe-Al system. Calphad 2002, 26, 573. [CrossRef]

24. Friák, M.; Neugebauer, J. Ab initio study of the anomalous volume-composition dependence in Fe-Al alloys. Intermetallics 2010, 18, 1316-1321. [CrossRef]

25. Amara, H.; Fu, C.C.; Soisson, F.; Maugis, P. Aluminum and vacancies in $\alpha$-iron: Dissolution, diffusion, and clustering. Phys. Rev. B 2010, 81, 174101. [CrossRef]

26. Liu, S.; Duan, S.; Ma, B. First-principles calculation of vibrational entropy for Fe-Al compounds. Phys. Rev. B 1998, 58, 9705-9709.

27. Kulikov, N.I.; Postnikov, A.V.; Borstel, G.; Braun, J. Onset of magnetism in B2 transition-metal aluminides. Phys. Rev. B 1999, 59, 6824-6833. [CrossRef]

28. Fähnle, M.; Drautz, R.; Lechermann, F.; Singer, R.; Diaz-Ortiz, A.; Dosch, H. Thermodynamic properties from ab-initio calculations: New theoretical developments, and applications to various materials systems. Phys. Status Solidi B-Basic Solid State Phys. 2005, 242, 1159-1173. [CrossRef]

29. Friák, M.; Deges, J.; Krein, R.; Frommeyer, G.; Neugebauer, J. Combined ab initio and experimental study of structural and elastic properties of $\mathrm{Fe}_{3} \mathrm{Al}$-based ternaries. Intermetallics 2010, 18, 1310. [CrossRef]

30. Kirklin, S.; Saal, J.E.; Hegde, V.I.; Wolverton, C. High-throughput computational search for strengthening precipitates in alloys. Acta Mater. 2016, 102, 125-135. [CrossRef]

31. Airiskallio, E.; Nurmi, E.; Heinonen, M.H.; Vayrynen, I.J.; Kokko, K.; Ropo, M.; Punkkinen, M.P.J.; Pitkanen, H.; Alatalo, M.; Kollar, J.; Johansson, B.; Vitos, L. High temperature oxidation of Fe-Al and Fe-Cr-Al alloys: The role of $\mathrm{Cr}$ as a chemically active element. Corros. Sci. 2010, 52, 3394-3404. [CrossRef]

32. Medvedeva, N.I.; Park, M.S.; Van Aken, D.C.; Medvedeva, J.E. First-principles study of Mn, Al and C distribution and their effect on stacking fault energies in fcc Fe. J. Alloy. Compd. 2014, 582, 475-482. [CrossRef]

33. Č́ížek, J.; Lukáč, F.; Procházka, I.; Kužel, R.; Jirásková, Y.; Janičkovič, D.; Anwand, W.; Brauer, G. Characterization of quenched-in vacancies in Fe-Al alloys. Physica B 2012, 407, 2659-2664. [CrossRef] 
34. Ipser, H.; Semenova, O.; Krachler, R. Intermetallic phases with $\mathrm{DO}_{3}$-structure: A statistical-thermodynamic model. J. Alloy. Compd. 2002, 338, 20-25. [CrossRef]

35. Miháliková, I.; Slávik, A.; Friák, M.; Všianská, M.; Koutná, N.; Holec, D.; Šob, M. First-principles study of interface energies in Fe-Al-based superalloy nanocomposites. In NANOCON 2017 Conference Proceedings (9th International Conference on Nanomaterials—Research \& Application, Brno, Oct. 18-20, 2017); Tanger Ltd.: Ostrava, Czech Republic; 2017; pp. 69-74.

36. Šesták, P.; Friák, M.; Holec, D.; Všianská, M.; Šob, M. Strength and Brittleness of Interfaces in Fe-Al Superalloy Nanocomposites under Multiaxial Loading: An ab initio and Atomistic Study. Nanomaterials 2018, 8, 873. [CrossRef] [PubMed]

37. Lechermann, F.; Welsch, F.; Elsässer, C.; Ederer, C.; Fähnle, M.; Sanchez, J.; Meyer, B. Density-functional study of $\mathrm{Fe}_{3} \mathrm{Al}$ : LSDA versus GGA. Phys. Rev. B 2002, 65, 132104. [CrossRef]

38. Connetable, D.; Maugis, P. First principle calculations of the kappa-Fe ${ }_{3} \mathrm{AlC}$ perovskite and iron-aluminium intermetallics. Intermetallics 2008, 16, 345-352. [CrossRef]

39. Lechermann, F.; Fähnle, M.; Meyer, B.; Elsässer, C. Electronic correlations, magnetism, and structure of Fe-Al subsystems: An LDA+U study. Phys. Rev. B 2004, 69, 165116. [CrossRef]

40. Kellou, A.; Grosdidier, T.; Raulot, J.M.; Aourag, H. Atomistic study of magnetism effect on structural stability in $\mathrm{Fe}_{3} \mathrm{Al}$ and $\mathrm{Fe}_{3} \mathrm{AlX}(\mathrm{X}=\mathrm{H}, \mathrm{B}, \mathrm{C}, \mathrm{N}, \mathrm{O})$ alloys. Phys. Status Solidi B-Basic Solid State Phys. 2008, 245, 750-755. [CrossRef]

41. Jiraskova, Y.; Pizurova, N.; Titov, A.; Janickovic, D.; Friak, M. Phase separation in Fe-Ti-Al alloy-Structural, magnetic, and Moessbauer study. J. Magn. Magn. Mater. 2018, 468, 91-99. [CrossRef]

42. Wang, K.; Wang, Y.; Cheng, Y. The Formation and Dynamic Evolution of Antiphase Domain Boundary in FeAl Alloy: Computational Simulation in Atomic Scale. Mater. Res. Ibero-Am. J. Mater. 2018, 21, e20171048. [CrossRef]

43. Balagurov, A.M.; Bobrikov, I.A.; Sumnikov, V.S.; Golovin, I.S. Antiphase domains or dispersed clusters? Neutron diffraction study of coherent atomic ordering in $\mathrm{Fe}_{3} \mathrm{Al}$-type alloys. Acta Mater. 2018, 153, 45-52. [CrossRef]

44. Murakami, Y.; Niitsu, K.; Tanigaki, T.; Kainuma, R.; Park, H.S.; Shindo, D. Magnetization amplified by structural disorder within nanometre-scale interface region. Nat. Commun. 2014, 5, 4133. [CrossRef] [PubMed]

45. Oguma, R.; Matsumura, S.; Eguchi, T. Kinetics of B2-and $\mathrm{D}_{3}$ type ordering and formation of domain structures in Fe-Al alloys. J. Phys. Cond. Matter 2008, 20, 275225. [CrossRef] [PubMed]

46. Hohenberg, P.; Kohn, W. Inhomogeneous electron gas. Phys. Rev. 1964, 136, B864-B871. [CrossRef]

47. Kohn, W.; Sham, L.J. Self-consistent equations including exchange and correlation effects. Phys. Rev. 1965, 140, A1133-A1138. [CrossRef]

48. Kresse, G.; Hafner, J. Ab initio molecular dynamics for liquid metals. Phys. Rev. B 1993, 47, 558-561. [CrossRef]

49. Kresse, G.; Furthmüller, J. Efficient iterative schemes for ab initio total-energy calculations using a plane-wave basis set. Phys. Rev. B 1996, 54, 11169-11186. [CrossRef]

50. Blöchl, P.E. Projector augmented-wave method. Phys. Rev. B 1994, 50, 17953-17979. [CrossRef]

51. Kresse, G.; Joubert, D. From ultrasoft pseudopotentials to the projector augmented-wave method. Phys. Rev. B 1999, 59, 1758. [CrossRef]

52. Ceperley, D.M.; Alder, B.J. Ground State of the Electron Gas by a Stochastic Method. Phys. Rev. Lett. 1980, 45, 566-569. [CrossRef]

53. Perdew, J.P.; Wang, Y. Accurate and simple analytic representation of the electron-gas correlation energy. Phys. Rev. B 1992, 45, 13244-13249. [CrossRef]

54. Vosko, S.H.; Wilk, L.; Nusair, M. Accurate spin-dependent electron liquid correlation energies for local spin density calculations: A critical analysis. Can. J. Phys. 1980, 58, 1200. [CrossRef]

55. Monkhorst, H.J.; Pack, J.D. Special points for Brillouin-zone integrations. Phys. Rev. B 1976, 13, 5188-5192. [CrossRef]

56. Zhou, L.; Holec, D.; Mayrhofer, P.H. First-principles study of elastic properties of Cr-Al-N. J. Appl. Phys. 2013, 113, 043511. [CrossRef]

57. Mayrhofer, P.H.; Fischer, F.D.; Boehm, H.J.; Mitterer, C.; Schneider, J.M. Energetic balance and kinetics for the decomposition of supersaturated $\mathrm{Ti}_{1-x} \mathrm{Al}_{x} \mathrm{~N}$. Acta Mater. 2007, 55, 1441-1446. [CrossRef] 
58. Wu, L.; Chen, M.; Li, C.; Zhou, J.; Shen, L.; Wang, Y.; Zhong, Z.; Feng, M.; Zhang, Y.; Han, K.; et al. Ferromagnetism and matrix-dependent charge transfer in strained $\mathrm{LaMnO}_{3}-\mathrm{LaCoO}_{3}$ superlattices. Mater. Res. Lett. 2018, 6, 501-507. [CrossRef]

59. Koutná, N.; Holec, D.; Friák, M.; Mayrhofer, P.H.; Šob, M. Stability and elasticity of metastable solid solutions and superlattices in the MoN-TaN system: First-principles calculations. Mater. Des. 2018, 144, 310-322. [CrossRef]

60. Jiang, M.; Xiao, H.Y.; Peng, S.M.; Yang, G.X.; Liu, Z.J.; Zu, X.T. A comparative study of low energy radiation response of AlAs, GaAs and GaAs/AlAs superlattice and the damage effects on their electronic structures. Sci. Rep. 2018, 8, 2012. [CrossRef]

61. Wen, Y.N.; Gao, P.F.; Xia, M.G.; Zhang, S.L. Half-metallic ferromagnetism prediction in $\mathrm{MoS}_{2}$-based two-dimensional superlattice from first-principles. Mod. Phys. Lett. B 2018, 32, 1850098. [CrossRef]

62. Friák, M.; Tytko, D.; Holec, D.; Choi, P.P.; Eisenlohr, P.; Raabe, D.; Neugebauer, J. Synergy of atom-probe structural data and quantum-mechanical calculations in a theory-guided design of extreme-stiffness superlattices containing metastable phases. New J. Phys. 2015, 17, 093004. [CrossRef]

63. Dai, Q.; Eckern, U.; Schwingenschlog, U. Effects of oxygen vacancies on the electronic structure of the $(\mathrm{LaVO} 3)_{6} / \mathrm{SrVO}_{3}$ superlattice: A computational study. New J. Phys. 2018, 20, 073011. [CrossRef]

64. Jiang, M.; Xiao, H.; Peng, S.; Qiao, L.; Yang, G.; Liu, Z.; Zu, X. First-Principles Study of Point Defects in GaAs/AlAs Superlattice: the Phase Stability and the Effects on the Band Structure and Carrier Mobility. Nanoscale Res. Lett. 2018, 13, 301. [CrossRef]

65. Chen, H.; Millis, A.J.; Marianetti, C.A. Engineering Correlation Effects via Artificially Designed Oxide Superlattices. Phys. Rev. Lett. 2013, 111, 116403. [CrossRef] [PubMed]

66. Mottura, A.; Janotti, A.; Pollock, T.M. A first-principles study of the effect of Ta on the superlattice intrinsic stacking fault energy of $\mathrm{L}_{2}-\mathrm{Co}_{3}(\mathrm{Al}, \mathrm{W})$. Intermetallics 2012, 28, 138-143. [CrossRef]

67. Rosengaard, N.; Skriver, H. Ab-initio study of antiphase boundaries and stacking-faults in $\mathrm{L}_{2}$ and $\mathrm{D}_{22}$ compounds. Phys. Rev. B 1994, 50, 4848-4858. [CrossRef]

68. Torres-Pardo, A.; Gloter, A.; Zubko, P.; Jecklin, N.; Lichtensteiger, C.; Colliex, C.; Triscone, J.M.; Stephan, O. Spectroscopic mapping of local structural distortions in ferroelectric $\mathrm{PbTiO}_{3} / \mathrm{SrTiO}_{3}$ superlattices at the unit-cell scale. Phys. Rev. B 2011, 84, 220102. [CrossRef]

69. Chawla, V.; Holec, D.; Mayrhofer, P.H. Stabilization criteria for cubic AlN in TiN/AlN and CrN/AlN bi-layer systems. J. Phys. D 2013, 46, 045305. [CrossRef]

70. Cooper, V.R.; Rabe, K.M. Enhancing piezoelectricity through polarization-strain coupling in ferroelectric superlattices. Phys. Rev. B 2009, 79, 180101. [CrossRef]

71. Chen, B.; Zhang, Q.; Bernholc, J. Si diffusion in GaAs and Si-induced interdiffusion in GaAs/AlAs superlattices. Phys. Rev. B 1994, 49, 2985-2988. [CrossRef]

72. Schmid, U.; Christensen, N.; Cardona, M.; Lukes, F.; Ploog, K. Optical anisotropy in GaAs/A1Ss(110) superlattices. Phys. Rev. B 1992, 45, 3546-3551. [CrossRef]

73. Gibson, Q.D.; Schoop, L.M.; Weber, A.P.; Ji, H.; Nadj-Perge, S.; Drozdov, I.K.; Beidenkopf, H.; Sadowski, J.T.; Fedorov, A.; Yazdani, A.; Valla, T.; Cava, R.J. Termination-dependent topological surface states of the natural superlattice phase $\mathrm{Bi}_{4} \mathrm{Se}_{3}$. Phys. Rev. B 2013, 88, 081108R. [CrossRef]

74. Park, C.; Chang, K. Structural and electronic-properties of GaP-AlP (001) superlattices. Phys. Rev. B 1993, 47, 12709-12715. [CrossRef]

75. Romanyuk, O.; Hannappel, T.; Grosse, F. Atomic and electronic structure of GaP/Si(111), GaP/Si(110), and $\mathrm{GaP} / \mathrm{Si}(113)$ interfaces and superlattices studied by density functional theory. Phys. Rev. B 2013, 88, 115312. [CrossRef]

76. Abdulsattar, M.A. SiGe superlattice nanocrystal pure and doped with substitutional phosphorus single atom: Density functional theory study. Superlattices Microstruct. 2011, 50, 377-385. [CrossRef]

77. Botti, S.; Vast, N.; Reining, L.; Olevano, V.; Andreani, L. Ab initio and semiempirical dielectric response of superlattices. Phys. Rev. B 2004, 70, 045301. [CrossRef]

78. Rondinelli, J.M.; Spaldin, N.A. Electron-lattice instabilities suppress cuprate-like electronic structures in $\mathrm{SrFeO}_{3} / \mathrm{OSrTiO}_{3}$ superlattices. Phys. Rev. B 2010, 81, 085109. [CrossRef]

79. Titrian, H.; Aydin, U.; Friák, M.; Ma, D.; Raabe, D.; Neugebauer, J. Self-consistent Scale-bridging Approach to Compute the Elasticity of Multi-phase Polycrystalline Materials. MRS Proc. 2013, 1524, rr06. [CrossRef] 
80. Friák, M.; Counts, W.; Ma, D.; Sander, B.; Holec, D.; Raabe, D.; Neugebauer, J. Theory-Guided Materials Design of Multi-Phase Ti-Nb Alloys with Bone-Matching Elastic Properties. Materials 2012, 5, 1853-1872. [CrossRef]

81. Zhu, L.F.; Friák, M.; Lymperakis, L.; Titrian, H.; Aydin, U.; Janus, A.; Fabritius, H.O.; Ziegler, A.; Nikolov, S.; Hemzalová, P.; Raabe, D.; Neugebauer, J. Ab initio study of single-crystalline and polycrystalline elastic properties of Mg-substituted calcite crystals. J. Mech. Behav. Biomed. Mater. 2013, 20, 296-304. [CrossRef]

82. Nakamura, M.; Matsumoto, S.; Hirano, T. Elastic constants of $\mathrm{MoSi}_{2}$ and $\mathrm{WSi}_{2}$ single crystals. J. Mater. Sci. 1990, 25, 3309-3313. [CrossRef]

83. Zhang, H.; Chen, P.; Yan, J.; Tang, S. Fabrication and wear characteristics of MoSi 2 matrix composite reinforced by $\mathrm{WSi}_{2}$ and $\mathrm{La}_{2} \mathrm{O}_{3}$. Int. J. Refract. Met. Hard Mater. 2004, 22, 271-275. [CrossRef]

84. Chu, F.; Ming, L.; Maloy, S.A.; Mitchell, T.E.; Migliori, A.; Garrett, J. Single crystal elastic constants of $\mathrm{NbSi}_{2}$. Philos. Mag. B 1995, 71, 373-382. [CrossRef]

85. Erturk, E.; Gurel, T. Ab initio study of structural, elastic, and vibrational properties of transition-metal disilicides $\mathrm{NbSi}_{2}$ and $\mathrm{TaSi}_{2}$ in hexagonal C40 structure. Phys. B Cond. Matter 2018, 537, 188-193. [CrossRef]

86. Wan, B.; Xiao, F.; Zhang, Y.; Zhao, Y.; Wu, L.; Zhang, J.; Gou, H. Theoretical study of structural characteristics, mechanical properties and electronic structure of metal $(\mathrm{TM}=\mathrm{V}, \mathrm{Nb}$ and $\mathrm{Ta})$ silicides. J. Alloys Compd. 2016, 681, 412-420. [CrossRef]

87. Moakher, M.; Norris, A.N. The closest elastic tensor of arbitrary symmetry to an elasticity tensor of lower symmetry. J. Elast. 2006, 85, 215-263. [CrossRef]

88. Tasnádi, F.; Abrikosov, I.A.; Rogström, L.; Almer, J.; Johansson, M.P.; Oden, M. Significant elastic anisotropy in Ti1-xAlxN alloys. Appl. Phys. Lett. 2010, 97, 231902. [CrossRef]

89. Tasnádi, F.; Odén, M.; Abrikosov, I. Ab initio elastic tensor of cubic $\mathrm{Ti}_{0.5} \mathrm{Al}_{0.5} \mathrm{~N}$ alloys: Dependence of elastic constants on size and shape of the supercell model and their convergence. Phys. Rev. B 2012, 85, 144112. [CrossRef]

90. Von Pezold, J.; Dick, A.; Friák, M.; Neugebauer, J. Generation and performance of special quasirandom structures for studying the elastic properties of random alloys: Application to Al-Ti. Phys. Rev. B 2010, 81, 094203. [CrossRef]

91. Holec, D.; Tasnádi, F.; Wagner, P.; Friák, M.; Neugebauer, J.; Mayrhofer, P.; Keckes, J. Macroscopic elastic properties of textured $\mathrm{ZrN}-\mathrm{AlN}$ polycrystalline aggregates: From ab initio calculations to grainscale interactions. Phys. Rev. B 2014, 90, 184106. [CrossRef]

92. Kou, K.; Yang, Y.; Ai, Y.; Chen, Y.; Kang, M. Self-propagating high-temperature combustion synthesis of $\mathrm{MoSi}_{2}-\mathrm{WSi}_{2}$ composite. Rare Met. Mater. Eng. 2000, 29, 190-192.

93. Zhang, Y.; Zhang, P.; Ren, J.; Zhang, L.; Zhang, J. SiC nanowire-toughened MoSi ${ }_{2}-\mathrm{WSi}_{2}-\mathrm{SiC}-\mathrm{Si}$ multiphase coating for improved oxidation resistance of C C composites. Ceram. Int. 2016, 42, 12573-12580. [CrossRef]

94. Ai, Y.; Cheng, Y.; Yang, Y.; Kang, M.; Liu, C. Preparation and microstructure of $\mathrm{WSi}_{2} / \mathrm{MoSi}_{2}$ composite heat element. Rare Met. Mater. Eng. 2005, 34, 962-965.

95. Xu, J.; Wu, H.; Li, B. Synthesis of $\mathrm{MoSi}_{2} / \mathrm{WSi}_{2}$ nanocrystalline powder by mechanical-assistant combustion synthesis method. Int. J. Refract. Met. Hard Mater. 2010, 28, 217-220. [CrossRef]

96. Zunger, A.; Wei, S.; Ferreira, L.; Bernard, J. Special quasirandom structures. Phys. Rev. Lett. 1990, 65, 353-356. [CrossRef] [PubMed]

97. Li, J.; Wang, C.; Yao, J.; Yang, S.; Kang, Y.; Shi, Z.; Liu, X. Experimental investigation of phase equilibria in the $\mathrm{Nb}-\mathrm{Si}$-Ta ternary system. Int. J. Mater. Res. 2016, 107, 1112-1120. [CrossRef]

98. Momma, K.; Izumi, F. VESTA 3 for three-dimensional visualization of crystal, volumetric and morphology data. J. Appl. Crystallogr. 2011, 44, 1272-1276. [CrossRef]

(c) 2018 by the authors. Licensee MDPI, Basel, Switzerland. This article is an open access article distributed under the terms and conditions of the Creative Commons Attribution (CC BY) license (http:/ / creativecommons.org/licenses/by/4.0/). 